\title{
CASE REPORT INGUINAL BLADDER HERNIATION: A CASE REPORT
}

\author{
INGUINAL MESANE HERNIASYONU: OLGU SUNUSU \\ ${ }^{1 *}$ Mustafa Reşorlu, ${ }^{1}$ Nilüfer Aylanç, ${ }^{1}$ Canan Akgün Toprak, ${ }^{1}$ Muhsin Özgün Öztürk
}

Mesanenin inguinal kanala herniasyonu oldukça nadirdir ve bu hastalar sıklıkla asemptomatiktir. Semptomatik olduklarında genelde nonspesifik üriner semptomlar vardır. Erken tanı konulması gelişebilecek komplikasyonların ve cerrahi sırasında iatrojenik mesane yaralanmalarının önlenmesinde önemlidir. Radyolojik görüntülemede altın standart sistografi olmakla birlikte preoperatif tanıda ek patolojilerin gösterilebilmesi amacıyla manyetik rezonans görüntüleme kullanılabilir.

Anahtar Sözcükler: Mesane herniasyonu, sistografi, bilgisayarlı tomografi

1 Çanakkale Onsekiz Mart University, Faculty of Medicine, Department of Radiology.

Received

21.12.2016

Accepted

13.01.2017

Corresponding Author

1*Mustafa Reşorlu, Çanakkale Onsekiz Mart University,Faculty of Medicine,

Department of Radiology.

e-posta: mustafaresorlu77@gmail.com

Herniation of the bladder into the inguinal canal is unusual, and these patients are frequently asymptomatic. When symptomatic, they generally exhibit nonspecific urinary symptoms. Early diagnosis is important in preventing potential complications and iatrogenic bladder injury during surgery. The gold standard in radiological imaging is cystography, but magnetic resonance imaging can be used to show additional pathologies at preoperative diagnosis.

Keywords: Bladder herniation, cystography, computerized tomography

\section{Introduction}

The incidence of inguinal hernia is approximately $3-8 \%$, and it is more common in males ${ }^{1}$. Herniation of the bladder inside the inguinal hernia sac is quite rare, and males aged over 50 constitute the majority of cases ${ }^{1}$.Herniation of the bladder into the inguinal canal constitutes $1-4 \%$ of all inguinal hernias and is frequently identified incidentally during inguinal surgery ${ }^{2}$. Various factors are implicated in the pathophysiology. Probable predisposing factors include weakness of the bladder detrusor and abdominal wall muscles, the hernia sac causing traction in the bladder, obesity and a previous history of inguinal surgery ${ }^{3}$. Most patients are asymptomatic.They may rarely exhibit nonspecific urinary symptoms. Early diagnosis is important due to the possibility of complications ${ }^{2,3}$. We describe a patient presenting with abdominal pain and inguinal swelling and diagnosed with bladder herniation based on imaging findings.

\section{Case Report}

A 68-year-old man with a history of cholecystectomy one year previously presented to our hospital with right flank pain and inguinal swelling. The patient described no diabetes or hypertension in his medical history. Physical examination revealed swelling in the right inguinal canal and right costovertebral angle tenderness.
Elevated LDL cholesterol (135 mg/dl) and glucose $(133 \mathrm{mg} / \mathrm{dl})$ levels were determined at routine biochemistry tests, but other biochemical parameters were normal. No pathology was determined at urine test or complete blood count. Stone was observed in the right kidney at noncontrast abdominal computerized tomography directed toward kidney and ureteral stone. Additionally, herniation of the right anterolateral corner of the bladder and ileum into the inguinal canal was observed (Fig 1,2).
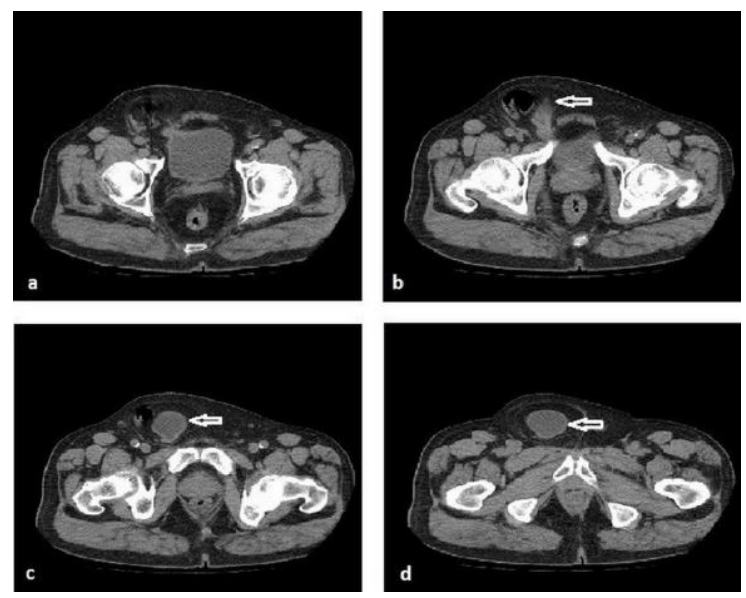

Figure 1. Herniation of the bladder and ileum into the right inguinal sac on axial $\mathrm{CT}$ sections. 

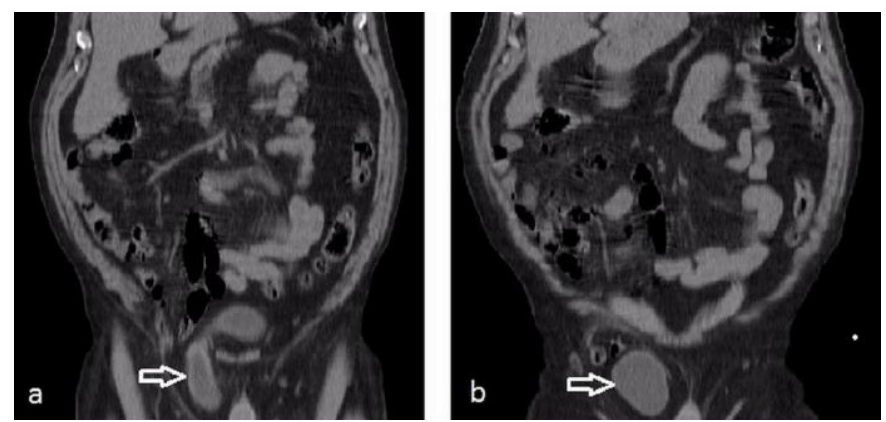

Figure 2. Bladder and ileum herniation into the inguinal canal on coronal reformatted images.

\section{Discussion}

Herniation of the bladder to the scrotum, known as scrotal cystocele, was first described by Levine in 1951 and is regarded as an acquired pathology ${ }^{4}$. It generally occurs on the right side, and the incidence increases over the age of $50^{1}$.Various systemic and local factors are implicated in the etiology. Advanced age, obesity, history of inguinal surgery, impaired bladder tonus and bladder detrusor muscles weakness are recognized as predisposing factors. Atrophy of the abdominal wall musculature, increased perivesical fat tissue and increased pressure associated with prostatic hypertrophy during urination can be the cause of herniation in the patients with advancing age.It has been suggested that all these factors can lead to diverticle formation and bladder herniation $^{5,6}$.

Most patients are asymptomatic, and diagnosis is made incidentally during radiological imaging performed for various reasons ${ }^{7}$. When symptomatic, urinary system symptoms such as dysuria and urination difficulty are seen in these cases $^{7}$. Patients may relief by emptying urine in the herniated section by pressing on it by hand after voiding the normal bladder ${ }^{8}$.

Early diagnosis is important in order to prevent complications and to minimalize iatrogenic injuries to the bladder during inguinal surgery. Radiological imaging is particularly taking an important role in avoiding from probable complications such as perforation, kidney failure, and strangulation ${ }^{7,9}$.

Radiological imaging techniques have various superiorities and deficiencies compared to one another. The gold standard in diagnosis is cystography, but this also has disadvantages, such as inability to show additional pathologies and false negativity in narrow neck hernias ${ }^{9}$. Impaired bladder morphology, inability to show the base of the bladder or abnormal position of the distal ureter at intravenous pyelography should suggest herniation. Additional pathologies accompanying herniation can be shown at CT, but this technique involves disadvantages compared to other methods, such as higher costs and exposing the patient to radiation. Advantages of magnetic resonance imaging include the ability to show the hernia's relations with peritoneal structures, accompanying additional pathologies, inflammatory changes and complications and that it does not involve exposure to radiation ${ }^{9,10}$.

Treatment is surgical, using resection or reduction. Advantages of reduction include preservation of bladder capacity and less ureter injury. Laparoscopic techniques have been using frequently in recent years ${ }^{11,12}$.

\section{References}

1. Koonz AR. Sliding hernia of diverticulum of bladder. AMA Arch Surg 1995; 70: 436.

2. Cavdar F, Göcer S, Eken H, Peker K, Celebi B, Yılmaz İ Nadir GörülenVeZorTanıKonulan İnguinal MesaneHernisi: 2 OlguSunumu. Düzce Tıp FakültesiDergisi 2014; 16(1): 58-59.

3. Jackman SV, Schulam PG, Schoenberg M. Pseudotumor of the bladder: a late complication of inguinal herniorraphy. Urology 1997;50:609-11.

4. Levine B. Scrotal cystosele. J Am Med Assoc 1951; 147: 1439-1441.

5. Ersoy E, Karagüzel E, Akgül T, Ayyıldız A, Germiyanoğlu C. Dev inguinoskrotalmesanehernisi: inguinal herniorafiningeçbirkomplikasyonu. Turkish J Urol 2009; 35(3): 266-7.

6. Bolton DM, Joyce G. Vesical diverticulum extending into an inguinal hernia. $\mathrm{Br}$ J Urol 1994;73: 323-4.

7. Yüceler Z, Savaş Y, Kırış A. Geniş inguinal mesaneherniasyonu, Olgusunumu. Haseki Tıp Bülteni 2010; 48: 113-5.

8. Ray B, Darwish ME, Baker RJ, Clark SS. Massive inguinoscrotal bladder herniation. J Urol 1997;118:330-1.

9. Caterino M, Finocchi V, Giunta S, De Carli P, Crecco M. Bladder cancer within a direct inguinal hernia: CT demonstration. Abdom Imaging 2001;26:664-6.

10. Andac N, Baltacioglu F, Tuney D, Cimflit NC, Ekinci G, Biren T Inguinoscrotal bladder herniation: is CT a useful tool in diagnosis? Clin Imaging 2002;26:347-8.

11. Khan A, Beckley I, Dobbins B, Rogawski KM. Laparoscopic repair of massive inguinal hernia containing the urinary bladder. Urol Ann 2014; 6(2): 159-62.

12. Malhotra MK, Kapoor Y. Pre surgical evaluation of scrotal cystocele by conventional radiography (cystogram). Niger J Surg. 2012; 18(1): 34-6. 